\title{
Daya saing produk unggulan sektor pertanian Indonesia dalam hubungannya dengan pertumbuhan Ekonomi
}

\author{
Parmadi*; Emilia; Zulgani \\ Prodi Ekonomi Pembangunan Fakultas Ekonomi dan Bisnis Universitas Jambi \\ *E-mail korespondensi: parmadi68pc@gmail.com
}

\begin{abstract}
This study aims to identify and analyze the competitiveness of Indonesian products in the agricultural sector, especially rice, oil palm, vegetables, fruits and livestock products, also the relation between economic growth and some commonly used competitiveness indicators. The approach used is RCA (Revealed Comparative Advantage), RSCA (Revealed Symetrics Comparative Advantage), Self Sufficiency Ratio (SSR), Import Dependency Ratio (IDR). The results of the study are as follows: The export performance of Indonesian agricultural products in general relatively weak. Almost all agricultural commodities have low competitiveness, except for plantation sub-sector products, especially rubber and palm oil which have high competitiveness, the remaining products such as horticulture, food crops, livestock products, and competitiveness of horticulture relatively low in the international commodity market. In this study, also found in general, the relation between the rate of economic growth and some magnitudes of international trade performance does not show a significant relationship for food crops, horticulture, plantations, and livestock products. Indonesia is approaching the stage of self-sufficiency, especially for food crops, but for other agricultural sector commodities, it is still very dependent on imports to meet domestic consumption needs.
\end{abstract}

Keywords: Competitiveness, IDR, RCA, SSR, RSCA, Agriculture Sector

\begin{abstract}
Abstrak
Penelitian ini bertujuan untuk mengetahui dan menganalisis daya saing produk di sektor pertanian Indonesia, terutama beras, minyak kelapa sawit, produk sayuran, buah-buahan dan produk ternak, serta mengetahui dan menganalisis hubungan antara pertumbuhan ekonomi dan beberapa indikator daya saing yang biasa digunakan. Pendekatan yang digunakan adalah RCA (Revealed Comparative Advantage), RSCA (Revealed Symetrics Comparative Advantage), Self Sufficiency Ratio (SSR), Rasio Ketergantungan Impor (IDR). Hasil penelitian adalah sebagai berikut: Kinerja ekspor produk pertanian Indonesia secara umum relatif lemah. Hampir semua komoditas pertanian memiliki daya saing rendah, kecuali untuk produk sub-sektor perkebunan, terutama karet dan kelapa sawit yang memiliki daya saing tinggi, sisanya produkproduk seperti hortikultura, tanaman pangan, produk ternak, dan daya saing hortikultura yang relatif rendah di pasar komoditas internasional. Dalam penelitian ini juga diketahui, secara umum hubungan antara laju pertumbuhan ekonomi dengan beberapa besaran kinerja perdagangan internasional tidak menunjukkan hubungan yang signifikan baik untuk tanaman pangan, hortikultura, perkebunan, dan produk ternak. Indonesia semakin mendekati tahap swasembada, terutama untuk tanaman pangan, tetapi untuk komoditas sektor pertanian lainnya, masih sangat tergantung pada impor untuk memenuhi kebutuhan konsumsi domestik.
\end{abstract}

Kata kunci: Daya Saing, RSK, RCA, IDR, RSCA, Sektor Pertanian 


\section{PENDAHULUAN}

Peran sektor pertanian dalam perekonomian Indonesia masih tergolong signifikan terutama bila dilihat dari beberapa indikator makro ekonomi seperti Produk Domestik Bruto (PDB), pertumbuhan ekonomi, kesempatan kerja dan ekspor. BPS (2017) dan Kementerian Pertanian (2017) mencatat, dari sisi pembentukan PDB, pada tahun 2012 sektor pertanian memberikan kontribusi sebesar 13,37 persen ( $R p 1.152,262$ milyar), yang pada tahun 2016 mengalami peningkatan menjadi 13,45 persen $(\mathrm{Rp} 1.668,997$ milyar, selama periode 2012-2016 telah terjadi peningkatan rerata sebesar 13,14 persen pertahun. Sebagai penyumbang nilai tambah terhadap PDB selama kurun waktu tersebut, sektor pertanian merupakan penyumbang kedua terbesar setelah sektor industri pengolahan. Apabila dilihat dari sisi penciptaan kesempatan kerja, sektor pertanian menjadi sektor utama dalam memberikan lapangan kerja di Indonesia. Kesempatan kerja di Indonesia mencatat bahwa selama tahun 2017 sektor pertanian menyerap tenaga kerja sebanyak 37.770 .165 orang, sementara itu data dari Kementerian Pertanian (2017) mencatat sebanyak 35.088 .823 orang.

Apabila dilihat dari indikator perdagangan luar negeri, ekspor produk yang berasal dari sektor pertanian juga semakin signifikan peranannya terhadap pola perdagangan internasional Indonesia. Dari Kementerian Pertanian pada tahun 2017 mencatat nilai ekspor komoditas pertanian Indonesia mencapai angka US\$ 26,370 milyar, agak menurun bila dibandingkan dengan tahun 2012 yang mencapai US\$33,678 milyar dollar atau turun rata-rata sebesar 7,83 persen pertahun. Penurunan kontribusi ekspor produk sektor pertanian Indonesia terhadap total eskpor Indonesia sangat mempengaruhi kinerja perekonomian Indonesia, khususnya dari sisi pertumbuhan ekonomi. Badan Pusat Statistik mencatat, pada tahun 2012 memperlihatkan laju pertumbuhan sektor pertanian memberikan kontribusi sebesar 0,51 persen terhadap laju pertumbuhan ekonomi Indonesia yang pada periode tersebut tercatat sebesar 6,23 persen (BPS, 2013). Hal ini berarti peran sektor pertanian dalam menciptakan sumber pertumbuhan ekonomi sangat signifikan. Oleh karena itu perlu dipertahankan agar pertumbuhan sektor pertanian dan peningkatan nilai tambahnya berbasis daya saing harus terus dikembangkan secara optimal, agar dapat memberikan manfaat bagi pertumbuhan dan pembangunan ekonomi pada masa mendatang.

Sebagai sektor strategis dalam perekonomian Indonesia, fluktuasi pembangunan pertanian terutama yang dilihat dari kinerja ekspor produk pertanian terlihat sangat riskan. Fluktuasi ekspor produk sektor pertanian akan sangat berpengaruh terhadap kesempatan kerja, pengurangan jumlah penduduk miskin, kondisi taraf hidup masyarakat yang tercermin dalam pendapatan perkapita, termasuk perolehan devisa negara. Oleh karena itu dayasaing sektor pertanian harus terus dibangun dan dikembangkan agar dapat memberikan kontribusi positif terhadap perekonomian Indonesia. Fluktuasi dan ketidakstabilan harga komoditas primer yang berasal dari sektor pertanian khususnya karet dan kelapa sawit yang selama ini menjadi primadona ekspor non migas Indonesia telah terbukti memberikan dampak negatif terhadap perekonomian Indonesia terutama dari sisi perolehan devisa. Hal ini pada gilirannya tentu akan sangat mempengaruhi pola dan dinamika pertumbuhan ekonomi Indonesia.

Dayasaing sektor pertanian perlu terus ditingkatkan guna memberikan landasan yang kuat bagi kinerja ekspor produk sektor pertanian. Berdasarkan kondisi ini diperlukan suatu telaah atau kajian tentang kinerja dayasaing produk pertanian Indonesia yang dilihat dari beberapa pendekatan antara lain indeks spesialisasi perdagangan, indeks keunggulan komparatif (Revealed Comparative Advantage dan Symetric Comparative Advantage), Import Dependency Ratio dan Self Sufficiency Ratio 


\section{METODE}

\section{Jenis dan sumber data}

Data yang digunakan dalam penelitian ini adalah data sekunder yang diperoleh dari lembaga-lembaga terkait seperti Badan Pusat Statistik, BAPPENAS, Bank Indonesia dan Kementerian Perdagangan. Jenis data yang digunakan adalah data ekspor, data impor, data produksi, data stok beberapa komoditas sektor pertanian yang menjadi unggulan untuk diperdagangkan pada pasar komoditas internasional, meliputi periode tahun 2008 hingga tahun 2016.

\section{Metode analisis data}

Metode yang digunakan dalam penelitian ini adalah metode analisis deskriptif kualitatif dan deskriptif kuantitatif. Untuk menjawab masalah pertama peneliti akan menggunakan beberapa alat analisis yang biasa digunakan untuk menganalisis kinerja perdagangan luar negeri suatu produk di antaranya

\section{Indeks spesialisasi perdagangan (ISP)}

Berdasarkan Kementerian Pertanian (2013, indeks yang digunakan untuk menganalisis posisi atau tahapan perkembangan suatu produk yang diperdagangkan dalam perdagangan internasional adalah Indeks Spesialisasi Perdagangan (ISP). ISP ini dapat menggambarkan posisi relatif suatu negara cenderung akan menjadi negara pengekspor atau negara pengimpor untuk suatu komoditas sektor pertanian yang diperdagangkan di pasar internasional. Adapun rumus ISP tersebut dapat ditulis $I S P=$ $\frac{X i-M i}{X i+M i}$, dimana: ISP $=$ indeks spesialisasi perdagangan, $\mathrm{X}=$ volume atau nilai ekspor komoditas Indonesia ke-i, dan $\mathrm{M}=$ volume atau nilai impor komoditas Indonesia ke-i

Secara relative nilai ISP ada pada kisaran Jika $-1 s / d-0,5$, berarti komoditas tersebut baru pada tahap pengenalan dalam perdagangan dunia atau memiliki daya saing rendah, dengan demikian Negara yang bersangkutan dapat dikategorikan sebagai negara pengimpor. Jika-0,4s/d 0,0 Berarti komoditas tersebut dikategorikan berada dalam tahap subsitusi impor dalam perdagangan dunia. Jika $0,1 \mathrm{~s} / \mathrm{d}$ 0,7 berarti komoditas tersebut dikategorikan berada dalam perluasan ekspor di dalam perdagangan dunia atau memiliki daya saing yang kuat dan jika $0,8 \mathrm{~s} / \mathrm{d} 1,0$ berarti komoditas tersebut berada dalam kategori atau tahap pematangan (maturity) dalam perdagangan dunia sehingga produk tersebut memiliki daya saing yang sangat kuat.

\section{Revealed comparative advantage (RCA)}

Revealed Comparative Advantage (RCA) atau Indeks Keunggulan Komparatif merupakan salah satu alat ukur yang sangat populer dalam menentukan dayasaing produk dihasilkan suatu negara yang dipasarkan pada pasar komoditas internasional. Indeks Keunggulan Komparatif ini sangat bermanfaat untuk merumuskan kebijakan perdagangan internasional untuk sebuah produk dan bahkan beberapa produk yang di ekspor ke pasar manca negara. Indeks RCA ini setidak-tidak dapat dijadikan sebagai pegangan bagi setiap negara untuk menentukan pilhan sektor atau komoditas mana yang dapat menghasilkan tambahan devisa kaena unggul dari sisi dayasaing. Rumus indeks keunggulan Komparatif tersebut adalah Indeks $R C A=\frac{X_{i j} / X_{j}}{X_{i w} / X_{w}}$, dimana : $\mathrm{X}_{\mathrm{ij}}=$ nilai ekspor komoditi $i$ dari negara $j, \mathrm{X}_{j}=$ total nilai ekspor non migas negara $\mathrm{j}, \mathrm{X}_{\mathrm{iw}}=$ nilai ekspor komoditi $i$ dari dunia, dan $\mathrm{X}_{\mathrm{w}}=$ total nilai ekspor non migas dunia

Sebuah produk akan memiliki dayasaing apabila memiliki koefisien RCA lebih besar dari 1, sebaliknya apabila koefisien RCA-nya lebih kecil dari $\mathbf{1}$ maka produk tersebut dinyatakan tidak berdayasaing. Dengan demikian angka RCA berkisar dimulai dari 0 sampai tak terhingga. Dengan menyadari kekurangan dalam indeks RCA, maka 
digunakanlah pendekatan Revealed Symetric Comparative Advantage (RSCA) dengan rumus: $\quad R S C A=\frac{(R C A-1)}{(R C A+1)} \quad$ Konsep RSCA ini membawa pergeseran yang cukup signifikan dalam memaknai arti dayasaing, dimana kisaran koefisien RCSA. secara teknis berkisar antara $\mathbf{- 1}$ hingga $\mathbf{1}$. Sehingga sebuah komoditas akan disebut memiliki dayasaing jika RSCA-nya berada di atas nol, dan sebaliknya dinyatakan tidak memiliki dayasaing jika RSCA-nya di bawah nol.

\section{Import dependency ratio}

Pendekatan ini memberikan penjelasan tentang ketergantungan suatu negara terhadap impor komoditas tertentu, penghitungan IDR tidak mencantumkan perubahan stok karena besarnya stok baik impor maupun produksi dalam negeri (domestik) sering tidak diketahui. Menurut FAO nilai IDR dapat dihitung dengan menggunakan rumus sebagai berikut: $I D R=\frac{\text { Impor }}{\text { Produksi+Impor-Ekspor }} \times 100$

\section{Self sufficiency ratio (SSR)}

Pada dasarnya koefisien SSR memberikan makna bahwa besarnya produksi yang selalu dikaitkan dengan kebutuhan dalam negeri. Adapun rumus SSR ini adalah sebagai berikut: $S S R=\frac{\text { Produksi }}{\text { Produksi+Impor-Ekspor }}$.

Sementara itu untuk menjawab masalah kedua peneliti akan menggunakan alat analisis koefisien korelasi rank Spearman yang lazim ditulis dengan rumus umum sebagai berikut:

Dimana :

$$
\text { Korelasi }=r_{x y}=\frac{n \sum x_{i} y_{i}-\sum x_{i} \sum y_{i}}{\sqrt{n \sum x_{i}^{2}-\left(\sum x_{i}\right)^{2}} \cdot \sqrt{n \sum y_{i}^{2}-\left(\sum y_{i}\right)^{2}}}
$$

Nilai $r$ selalu terletak antara -1 dan +1 Nilai $r$ tidak berubah apabila seluruh data baik pada variabel $\mathrm{x}$, variabel $\mathrm{y}$, atau keduanya dikalikan dengan suatu nilai konstanta (c) tertetu (asalkan $\mathrm{c} \neq 0$ ). Nilai $\mathrm{r}$ tidak berubah apabila seluruh data baik pada variable $\mathrm{x}$, variable $y$, atau keduanya ditambahkan dengan suatu nilai konstanta (c) tertentu. Nilai $r$ tidak akan dipengaruhi oleh penentuan mana variable $\mathrm{x}$ dan mana variable $\mathrm{y}$. Kedua variable bisa saling dipertukarkan. Nilai $r$ hanya untuk mengukur kekuatan hubungan linier, dan tidak dirancang untuk mengukur hubungan non linier

\section{Operasional variabel}

Ada beberapa konsep yang sekaligus menjadi variabel penelitan yang harus dijelaskan dalam penelitan ini. Adapun variabel tersebut adalah :

1. Pertumbuhan ekonomi merupakan peningkatan nilai produksi barang dan jasa atau peningkatan PDB pada periode observasi dinyatakan dalam persen

2. Komoditas unggulan merupakan komoditas yang memiliki dayasaing tinggi dalam komposisi sektor pertanian Indonesia dinyatakan dalam nilai rupiah

3. Dayasaing adalah tahapan kemampuan produk sektor pertanian untuk diperdagangkan yang nilainya akan dihitung dengan pendekatan RCA, RSCA, SSR, ISP dan IDR diukur dalam satuan rasio

4. Indeks Keunggulan Komparatif adalah indeks yang menyatakan keunggulan komparatif yang dimiliki oleh suatu negara terhadap suatu produk yang dipasarkan dalam pasar komoditas internasional, dalam satuan rasio

5. Sulf Sufficiency Ratio adalah ratio yang menyatakan besarnya produksi pada suatu negara yang dikaitkan dengan kebutuhan dalam negeri,dalam satuan rasio 
6. Indeks Spesialisasi perdagangan adalah indeks yang mampu menganalisis posisi atau tahapan perkembangan suatu produk yang diperdagangkan dalam perdagangan internasional, dalam satuan ukur rasio

7. Indeks ketergantungan impor adalah indeks yang menyatakan besarnya ketergantungan negara terhadap impor komoditas tertentu diukur dalam satuan rasio

\section{HASIL DAN PEMBAHASAN}

\section{Perkembangan sektor pertanian}

Peranan sektor pertanian dalam pembentukan PDB masih cukup signifikan.. Pada tahun sektor 2016 sektor pertanian memberikan kontribusi sebesar 10.21 persen terhadap pembentukkan Produk Domestik Bruto (PDB) nilai tambah sektor pertanian pada periode yang sama mencapai angka 1.668,998 trilyun rupiah. Pada tahun 2017 menjadi 13.14 persen, sedangkan nilai tambah sektor pertanian pada tahun 2017 turun menjadi Rp 1.256,894 milyar. (Statistik Indikator Makro Sektor Pertanian, Triwulan I, 2018). mengalami peningkatan menjadi Sementara itu nilai ekspor produk pertanian pada tahun 2016 telah mencapai angka US\$ 26,73 milyar, dan dalam waktu yang bersamaan nilai impor produk pertanian Indonesia mencapai angka US\$15,84 milyar (Statistik Makro Sektor Pertanian, 2017).

Untuk sektor investasi, total realisasi penanaman modal dalam negeri tahun 2012 berjumlah Rp 20,36 trilyun meningkat menjadi Rp 27,7889 trilyun pada tahun 2016, walaupun pada 2 tahun sebelumnya yakni tahun 2015 dan 2014 sempat terjadi penurunan dalam realisasi penanaman modal dalam negeri (PMDN) yang jumlahnya hanya mencapai Rp 17.5093 trilyun dan Rp 16, 5203 trilyun. Sementara itu untuk penanaman modal asing (PMA) pada sektor pertanian cenderung fluktuatif. Pada tahun 2012, arus penanaman modal asing untuk sektor pertanian sebesar US\$ 5,9331 milyar, mengalami penurunan menjadi US\$ 4,4831 milyar, walapun sempat meningkat cukup signifikan pada tahun 2015 dan 2014 dengan total investasi masing-masing US\$ 6,2364 milyar dan US\$ 6.9912 (Kementerian Pertanian, 2017)

Pembangunan sektor pertanian dalam dua puluh tahun terakhir ini telah banyak mengalami pergeseran dan modernisasi pertanian dalam era globalisasi telah menyebabkan sektor pertanian tumbuh dan berkembang dengan pesat. Paradigma pembangunan pertanian berbasis pada agribisnis dan agroindustri menjadikan peran sektor pertanian dalam perekonomian semakin penting dan kompleks. Pergerakan paradigma pertanian yang beorientasi peningkatan nilai tambah dan peningkatan dayasaing mendorong perlunya pengakajian dan pengembangan sektor pertanian secara berkelanjutan.

Interaksi yang terjalin dalam siklus perdagangan internasional di era globalisasi menjadikan sektor pertanian sebagai sektor yang turut berperan dalam dinamika perdagangan internasional dewasa ini. Perdagangan komoditas pertanian di pasar internasional (pasar global) harus terlebih dahulu mengembangkan produk pertanian secara sistematis dengan tujuan untuk meraih nilai tambah dan peningkatan dayasaing produk pertanian yang dipasarkan di pasar komoditas internasional. Program pengembangan dan pembangunan sektor pertanian di Indonesia masih perlu terus dibenahi, mengingat beberapa indikator penting dalam pembangunan pertanian terutama yang terkait dengan kinerja sektor pertanian dari aspek perdagangan internasionl masih belum memperlihatkan perkembangan yang berarti, bila dilihat dari indikataor : kemampuan daya saing sektor pertanian, indeks spesialisasi perdagangan, indeks ketergantungan impor, dan indeks ketersediaan produksi dalam negeri untuk kebutuhan konsumsi. 
Pada dasarnya komoditas pertanian yang dipasarkan pada pasar komoditas internasional dapat dikaji secara komprehensif melalui berbagai macam pendekatan yang bertujuan untuk melihat kemampuan sektor pertanian baik secara mikro maupun makro dalam perekonomian negara. Ada beberapa ukuran standar yang lazim digunakan untuk melihat dayasaing sektor pertanian, tingkat spesialisasi sektor pertanian dan beberapa ukuran statistik lainnya yang dapat digunakan untuk mendeteksi kinerja perdagangan sektor pertanian.

\section{Indeks spesialisasi perdagangan}

Untuk melihat dinamika perkembangan indeks spesialisasi perdagangan sektor pertanian dan beberapa subsektor diketahui bahwa untuk beberapa produk pertanian, ternyata Indonesia belum memiliki daya saing dalam pemasaran produk pertaniannya pada pasar komoditas internasional. Secara tegas diperlihatkan untuk komoditas tanaman pangan secara umum selama periode 2012 - 2016, memiliki nilai koefisien ISP masing-masing berkisar antara -0.96 hingga -0.98. Angka diinterpretasikan bahwa produk tanaman pangan Indonesia yang dipasarkan pada pasar komoditas pertanian dayasaingnya relatif sangat rendah. Komposisi perdagangan internasional untuk produk tanaman pangan pada tahun 2016 adalah ekspor sebesar 260.281 ton, sedangkan untuk impor sebesar 20.693.851 ton, sebagian besar yang diimpor adalah beras. Indonesia mengalami defisit untuk neraca perdagangan beras. Selama periode 2012 hingga 2016, koefisien ISP memperlihatkan angka masing-masing -0.94 hingga -0.96 dihitung berdasarkan komponen nilai mata uang, sedangkan bila dihitung berdasarkan pendekatan ukuran volume, kisaran ISP Indonesia adalah -0.96 hingga -0.98 . Gambaran ISP tanaman pangan tampaknya cukup ironis., mengingat posisi Indonesia sebagai negara pertanian yang memiliki kemampuan untuk mengolah berbagai potensi sumberdaya alam termasuk lahan pertanian yang sangat cocok untuk pengembangan tanaman pangan. Parameter lain yang dibutuhkan untuk pengembangan seperti iklim, tingkat kesuburan lahan, petani tersedia dalam jumlah yang cukup memadai, tetapi kemampuan untuk mengelola potensi tersebut tampaknya belum dapat dilakukan secara optimal, akibatnya ketergantungan Indonesia terhadap produk pangan impor tetap tinggi.

Sementara itu, untuk subsektor hortikultura (produk sayur-sayuran dan buahbuahan), kondisinya tidak jauh berbeda dengan produk tanaman pangan. Angka ISP untuk produk hortikultura Indonesia selama periode analisis 2012 hingga 2016 juga menggambarkan kondisi dimana produk hortikultura Indonesia belum memiliki daya saing (atau dayasaingnya relative rendah) hal ini diperlihatkan dengan capaian ISP antara -0.43 hingga --0.58 bila diukur dengan pendekatan nilai transaksi perdagangan. Bila diukur dengan parameter volume perdagangan maka ISP untuk produk hortikultura Indonesia berkisar -0.46 hingga -0.65 . Untuk subsektor peternakan, ISP juga mencerminkan dayasaing yang rendah (atau belum memiliki daya saing) hal ini diindikasikan dengan nilai ISP negatif selama periode analisis 2012 hingga 2016. Angka total ekspor dan impor untuk subsektor peternakan juga defisit, dimana total hewan ternak yang di eskpor jauh lebih kecil dari hewan ternak yang di impor.

Pada tahun 2012 total ternak yang di ekspor berjumlah 202.980 ton sedangkan impor sebesar 1.215.551 ton, ini terus berlangsung hingga tahun 2016 saat total ekspor ternak Indonesia mencapai angka 208.486 ton dengan impor ternak pada berjumlah 1.645.119 ton. Ketergantungan Indonesia dengan ternak impor sebagian besar ada pada jenis daging segar (atau daging sapi). Ketergantungan ini tampaknya bersifat kontinyu karena dari tahun ke tahun belum ada solusi konkrit untuk mengatasi ketergantungan terhadap produk daging segar yang konsumsinya selalu meningkat dari waktu ke waktu. 
Tata kelola dan tataniaga produk-produk strategis yang berkaitan dengan hajat hidup massyarakat tampaknya harus dilakukan secepat mungkin, karena kondisi ini akan dapat mempengaruhi daya beli, inflasi dan cadangan devisa dan kondisi ini dalam jangka panjang akan mempengaruhi daya tahan perekonomian nasional.

Satu dari sedikit produk pertanian Indonesia yang memiliki daya saing di pasar global adalah produk dari subsektor perkebunan yang didominasi oleh kelapa sawit dalam bentuk crude palm oil (CPO) dan karet. Untuk komoditas ini, Indonesia menjadi salah satu negara terdepan dalam indeks dayasaing yang berarti ISP untuk komoditas ini positif. Selama periode analisis periode tahun 2012 hingga 2016, Indonesia mengekspor CPO dan karet sebanyak 29.823.993 ton dan 34.628.849 ton dengan koefisien ISP berkisar antara 0.71 hingga 0.78 (dihitung berdasarkan nilai ekspor), jika dihitung berdasarkan volume maka ISP subsektor perkebunan selama periode analisis berkisar antara 0.71 hingga 0.98. Selama periode yang sama, Indonesia tetap mengimpor komoditas dari subsector perkebunan sebesar 3.859.155 ton di tahun 2012 dan 5.889.664 ton pada tahun 2016. Ketergantungan yang sangat kuat terhadap komoditas ekspor komoditas subsektor perkebunan sering menimbulkan masalah mendasar dalam perekonomian Indonesia seperti perolehan devisa dari sektor ekspor non migas menjadi sangat tergantung dengan ekspor komoditas pertanian, khususnya dari subsektor perkebunan. Penurunan harga komoditas subsektor perkebunan terkait berhubungan linear dengan peningkatan angka kemiskinan dan pengangguran, dan menurunnya daya beli masyarakat menjadi masalah berikutnya dari fluktuasi harga komoditas tersebut di pasar internasional.

Untuk menyikapi kondisi ini, pemerintah harus untuk melakukan transformasi proses pengolahan komoditas subsector perkebunan menuju pada produk yang lebih memiliki komposisi nilai tambah tinggi dan berdaya saing secara regional maupun secara global. Perlu diingat bahwa produk subsektor perkebunan telah menjadi bagian terpenting dari proses kehidupan sosial ekonomi masyarakat terutama di wilayah perdesaan.

\section{Penghitungan nilai SSR dan IDR}

Posisi SSR dan IDR untuk beberapa jenis komoditas sektor pertanian yang menjadi andalan Indonesia. Komoditas-komoditas antara lain mencakup beras, sayursayuran, buah-buahan, produk subsektor perkebunan serta subsektor peternakan. Perkembangan rasio ketergantungan terhadap beberapa komoditas pertanian yang dubutuhkan untuk memenuhi kebutuhan dalam negeri (domestik) ini biasanya disebut dengan import dependency ratio (IDR) serta besarnya produksi dalam kaitannya dengan kebutuhan dalam negeri yang lazim disebut sebagai self sufficiency ratio (SSR). Untuk komoditas tanaman pangan khususnya beras. IDR Indonesia sebenarnya hanya berkisar antara 0.01 hingga 0.06 selama periode analisis 2012-2016, artinya tingkat ketergantungan impor terhadap komoditas strategis beras Indonesia berkisar antara 0.01 hingga 0.06. Dengan kata lain untuk memenuhi kebutuhan konsumsi dalam negeri pemerintah hanya perlu mengimpor sebesar 1 persen hingga 6 persen, karena selebihnya telah tersedia didalam negeri (hasil produksi di dalam negeri).

Ketersediaan produksi dalam negeri khususnya untuk komoditas beras telah berada pada kisaran 94 hingga 98 persen. Biasanya yang menjadi masalah adalah dari sisi kuantitatif besaran kebutuhan akan beras impor tersebut cukup besar antara 400.000 ton hingga 2.000.000 ton, angka ini yang cukup fantastis dan memiliki implikasi yang luas terhadap devisa, stabilitas harga, daya beli dan kondisi perekonomian secara keseluruhan. Untuk komoditas sayuran, kondisi sebenarnya tidak terlalu berbeda dengan komoditas beras dimana tingkat ketergantungan dengan sayuran 
impor relatif kecil yaitu sekitar 0.06 hingga 0.07 selama periode analisis 2012-2016., artinya hanya 6 hingga 7 persen sayuran yang mesti di impor, selebihnya telah berhasil diproduksi didalam negeri. Angka ketersediaan produksi dalam negeri (stock of supply) berkisar antara 94 hingga 95 persen. Namun apabila dilihat dari sisi volume, angka tersebut tergolong cukup besar karena untuk memenuhi kebutuhan konsusmi dalam negeri Indonesia harus mengimpor rata-rata 700.000 hingga 800.000 ton sayuran pertahun.

Selama periode analisis,tingkat ketergantungan dengan buah-buahan impor juga sebenarnya relative kecil. Selama periode analisis 2012-2016 tingkat ketergantungan terhadap buah-buahan impor hanya berkisar antara 0.02 (2\%) hingga 0.03 (3\%). Dengan kata lain tingkat produksi buah-buahan dalam negeri telah mencapai angka 97 persen hingga 98 persen. Bila dilihat dari sisi kuantitatif persentase tersebut tetap cukup besar, dimana secara periodik setiap tahun rata-rata Indonesia membutuhkan buahbuahan impor sebanyak 300.000 ton hingga 600.000 ton pertahun. Dalam kaitannya dengan ketersediaan produksi dalam negeri, sebenarnya stok produksi dalam negeri selama periode analisis telah mencapai angka 97 hingga 99 persen. Artinya secara teknis produksi.Indonesia sudah semakin mendekati swasembada buah-buahan. Untuk komoditas hasil ternak, selama periode analisis 2012-2016 Indonesia memiliki ketergantungan impor rata-rata sebesar 33 hingga 36 persen. Dari sisi ketersediaan produksi ternak didalam negeri jumlahnya baru mencapai angka 70 hingga 72 persen, artinya untuk memenuhi kebutuhan konsumsi daging ternak khususnya daging sapi segar Indonesia harus mengimpor dalam jumlah yang cukup besar yakni sekitar 1,2 juta ton hingga 1.6 juta ton pertahun. Kondisi ini tentu akan sangat terkait dengan besaran devisa, kemampuan daya beli, tingkat konsumsi dalam negeri, tingkat harga dan stabilitas perekonomian secara keseluruhan.

Sementara itu untuk komoditas perkebunan, Indonesia telah mampu mencapai tahapan surplus di samping berhasil memenuhi kebutuhan dalam negeri, juga mampu mengekspor komoditas perkebunan, khususnya minyak kelapa sawit dan karet. Hal ini ditunjukkan dengan tingkat surplus rata-rata diatas 3 persen pertahun. Untuk produk atau komoditas perkebunan yang lain (non kelapa sawit dan karet) tampaknya Indonesia tetap harus mengimpor juga dalam jumlah yang cukup besar rata-rata sekitar 3 hingga 5 juta ton pertahun selama periode analisis. Salah satu komoditas yang akan dihitung indeks dayasaingnya adalah komoditas beras. Komoditas beras merupakan komoditas paling strategis dalam kancah politik ekonomi pertanian Indonesia. Komoditas pangan ini merupakan komoditas yang tidak hanya dilihat dari perspektif pertanian, namun harus pula dilihat dari perspektif politik khususnya dari sisi kemampuan komoditas beras guna menciptakan stablitas nasional. Dalam upaya untuk menjaga momentum ini, pemerintah selalu berupaya menjaga dan mengamati pergerakan harga beras. Fuktuasi harga beras yang tidak dapat dikendalikan pemerintah akan mendorong terjadinya instabilitas ekonomi yang pada gilirannya akan menimbulkan gejolak ekonomi dan sosial dalam masyarakat.

Komoditas beras Indonesia ternyata secara umum tidak memiliki dayasaing di pasar komoditas internasional. Hal ini didasarkan pada hasil penghitungan Indeks RSCA selama periode 2012 hingga 2016 yang memperlihatkan angka negatif, dengan kisaran koefisien RSCA antara -0,982 hingga -0,989. Untuk sementara, berdasarkan kondisi tersebut tentu sebaiknya Indonesia mengambil langkah untuk tetap fokus pada upaya pemenuhan kebutuhan dalam negeri, paling tidak untuk jangka pendek. 
Tabel 1. Revealed Comparative Advantage (RCA) dan Revealed Symmetric Comparative Advantage (RSCA) komoditas beras di Indonesia periode 2012-2016 (nilai ekspor dalam US\$ 000)

\begin{tabular}{llrrrrr}
\hline No & Keterangan & $\mathbf{2 0 1 2}$ & $\mathbf{2 0 1 3}$ & $\mathbf{2 0 1 4}$ & $\mathbf{2 0 1 5}$ & $\mathbf{2 0 1 6}$ \\
\hline 1 & Total Beras (Nilai & & & & & \\
& Ekspor dalam (000 & & & & & 1,526 \\
& USD) & 1,334 & 1,378 & 1,264 & 1,536 & $18,407,208$ \\
& Indonesia & $23,938,734$ & $25,406,707$ & $26,014,718$ & $22,736,188$ & \\
& Dunia*) & & & & $131,384,372$ \\
& Non Migas & $153,054,584$ & $149,918,763$ & $145,962,037$ & $131,791.907$ & 137,759, \\
& Indonesia & 15,237, & $15,785,753,5$ & $16,014,544$, & $14,524,621,1$ & $14,485,759$ \\
2 & Dunia*) & 757,429 & 82 & 872 & 13 & 871 \\
& Rasio & & & & 0,00001 \\
& Indonesia & 0,00001 & 0,00001 & 0,00001 & 0,00001 & 0,0013 \\
3 & Dunia & 0,0016 & 0,0016 & 0,0016 & 0,0016 & 0,01 \\
& RCA & 0,006 & 0,006 & 0,005 & 0,007 & $-0,982$ \\
\hline & RSCA & $-0,989$ & $-0,989$ & $-0,989$ & $-0,985$ &
\end{tabular}

Sumber : BPS dan Trademap, data diolah Keterangan*) Tahun 2016 Angka sementara (Diolah)

\section{Hubungan laju pertumbuhan ekonomi dengan ISP, IDR, dan SSR}

Pertumbuhan ekonomi Indonesia selama periode 2012 - 2015 cenderung menurun walaupun tidak terlalu signifikan. Pada tahun 2102 laju pertumbuhan ekonomi Indonesia sebesar 6.03 persen, mengalami penurunan menjadi 5,56 persen pada tahun 2013, kemudian dua tahun berikutnya di tahun 2014 laju pertumbuhan ekonomi menjadi 5,01 persen dan $2015(4,88 \%)$. Penurunan laju pertumbuhan ekonomi ini disebabkan harga-harga komoditas internasional primadona ekspor komoditas primer Indonesia mengalami penurunan dan berdampak negatif terhadap sumber perolehan devisa yang mengganggu kinerja ekspor dan pertumbuhan ekonomi. Harga minyak mentah dan harga komoditas hasil industri manufaktur yang tidak begitu signifikan juga berdampak buruk terhadap neraca transaksi berjalan Indonesia. Kondisi ini merupakan pencerminan ketergantungan terhadap ekspor produk primer yang terbukti sangat cepat mempengaruhi kinerja perekonomian. Hubungan antara laju pertumbuhan ekonomi dengan beberapa variabel pokok dalam komposisi kinerja perdagangan luar negeri untuk sektor pertanian dari hasil pengolahan data menggunakan software SPSS 22 diperoleh hasil sebagai berikut :

\section{Komoditas tanaman pangan}

Hubungan antara laju pertumbuhan ekonomi dengan ISP bersifat negatif dan tidak signifikan serta tidak ada korelasi, dengan IDR hubungannya bersifat positif tapi tidak signifikan derajad hubungan tersebut sedang, dengan SSR hubungannya bersifat negatif dan tidak signifikan derajad hubungannya sedang, dengan RSCA arah hubungannya negatif juga tidak signifikan sedangkan derajad hubungannya kuat, dan antara laju pertumbuhan ekonomi dengan RCA arah hubungannya negatif

dan tidak signifikan sedangkan derajad hubungannya tidak ada korelasi

\section{Komoditas hortikultura}

Antara laju pertumbuhan ekonomi dengan ISP bersifat negatif dan tidak signifikan, derajad hubungannya sempurna, dengan IDR hubungannya bersifat negatif dan tidak signifikan, sedangkan derajad hubungannya tidak berkorelasi, dan dengan SSR, hubungannya bersifat positif tapi tidak signifikan, derjad hubungannya sedang

\section{Komoditas perkebunan}

Hubungan antara laju pertumbuhan ekonomi dengan ISP, bersifat negatif dan tidak signifikan, derajad hubungan kuat, dengan IDR bersifat negatif dan tidak signifikan, derajad hubungannya kuat, dan dengan SSR, hubungannya negatif dan tidak signifikan, derajad hubungannya sempurna

\section{Komoditas hasil ternak}

Hubungan antara laju pertumbuhan ekonomi dengan ISP hubungannya positif, tapi tidak signifikan, derajat hubungan kuat, dengan IDR, hubungannya bersifat negatif 
dan tidak signifikan, derajad hubungan lemah, dan dengan SSR, hubungannya bersifat positif, tapi tidak signifikan, derajat hubungannya lemah

Antara laju pertumbuhan ekonomi dengan beberapa variabel kinerja perdagangan produk pertanian secara internasional ternyata lebih banyak berkorelasi negatif dan tidak signifikan (berjumlah 10 buah). Ini berarti perlu tindakan komprehensif dan tata kelola yang responsif, akuntabel dan transparan dalam mengelola kinerja sektor pertanian baik secara makro dan mikro. Hal ini mengingat peran sektor pertanian dalam perekonomian Indonesia masih sangat signifikan terutama bila dihubungkan dengan peningkatan pendapatan, perluasan kesempatan kerja dan kesempatan berusaha, perolehan devisa, peingkatan daya saing produk pertanian di pasar global, efek terhadap daya beli dan stabilitas harga serta stabilitas sosial, ekonomi dan politik secara keseluruhan.

\section{KESIMPULAN DAN SARAN}

\section{Kesimpulan}

Kinerja ekspor produk pertanian Indonesia umumnya relatif lemah. Hampir semua komoditas pertanian memiliki daya saing rendah, kecuali produk subsektor perkebunan (karet dan kelapa sawit) yang memiliki dayasaing cukup tinggi, selebihnya produkproduk seperti hortikultura, tanaman pangan, dan hasil ternak dayasaingnya relatif rendah di pasar komoditas internasional. Secara umum hubungan antara laju pertumbuhan ekonomi dengan beberapa besaran kinerja perdagangan internasional tidak memperlihatkan hubungan signifikan baik tanaman pangan, hortikultura, perkebunan, maupun produk peternakan. Indonesia telah semakin mendekati tahap swasembada khususnya untuk jenis tanaman pangan, tapi untuk komoditas-komoditas sektor pertanian lainnya, masih sangat tergantung dengan impor dalam rangka mencukupi kebutuhan konsumsi dalam negeri.

\section{Saran}

Diperlukan tata kelola yang lebih baik untuk meningkatkan kinerja pengembangan sektor pertanian agar dapat memberikan kontribusi positif terhadap perekonomian baik dalam jangka pendek maupun dalam jangka panjang. penguatan dan pengembangan kapasitas sistem pembangunan pertanian melalui pengembangan jaringan agribisnis dan agroindustri berbasis potensi sumberdaya setempat dalam rangka peningkatan dayasaing sektor pertanian serta optimalisasi nilai tambah sektor pertanian dalam perekonomian nasional

\section{DAFTAR PUSTAKA}

Arifin, B. (2005).Pembangunan Pertanian Paradigma Kebijakan dan Strategi Revitalisasi. Cetakan Pertama,PT Gramedia Widiasarana: Jakarta

Awina, O., Zulfanetti, Yulmardi. (2017). Analisis Produktivitas Tenaga Kerja Sektor Pertanian di Sumatera. Jurnal Paradigma Ekonomika. 12 (2), 49-56

Baharsjah,S,et.al. (2014).Reposisi Politik Pertanian Meretas Arah Baru Pembangunan Pertanian. Yayasan Pertanian Mandiri, Jakarta

BPS. (2017). Statistik Indonesia 2017 .Badan Pusat. Jakarta

Gumilar,W., Muhammad,S., Parmadi. (2017).Kontribusi dan elastisitas subsektor dalam sektor pertanian di Kabupaten Tebo. Jurnal Paradigma Ekonomika 12 (2), 77-86

Jagdambe,S. (2016).Analysis of Export Competitiveness of Indian Agricultural Products with Asian Countries.Working Paper 356. ISBN The Institute of Social and Economic Change, Bangalore 978-81-7791-212-8.

Riaz,K., Hans G.P. Jansen. (2012). Spatial Patterns of Revealed Comapartive Advantage of Pakistan 's Agricultural Export. Pakistan Economic and Social Review, 50(2), 97-120

Zulgani, Syaparuddin, Parmadi. (2014). Analisis Daya Saing Produk Agroindustri Subsektor Perkebunan dalam Perekonomian Wilayah Provinsi Jambi. Jurnal Perspektif Pembiayaan dan Pembangunan Daerah. 2(1),29-38 